\title{
Työhyvinvointi maatiloilla: stressi, työturvallisuus eläinten hoitotyössä ja naisten työolosuhteet maidontuotantotiloilla
}

\author{
Marja Kallioniemi ${ }^{1)}$ ja Hanna-Riitta Kymäläinen ${ }^{2)}$ \\ 1)MTT Taloustutkimus, Vakolantie 55,03400Vihti,marja.kallioniemi@mtt.fi \\ 2) Helsingin yliopisto, maataloustieteiden laitos, PL 28, 00014 Helsingin yliopisto, \\ hanna-riitta.kymalainen@helsinki.fi
}

\section{TIIVISTELM ̈̈}

Artikkeliväitöskirjan kokoavana teemana on työhyvinvointi suomalaisilla maatiloilla. Vuonna 2004 toteutettuun puhelinhaastatteluun vastasi 1182 päätoimista viljelijää. Toinen, laadullinen aineisto kerättiin kesällä 2007 kymmeneltä maidontuotantotilalta haastatellen ja havainnoiden naisten työtä.

Päätoimiset viljelijät kokivat haastatteluaineiston mukaan vähemmän stressiä kuin työikäinen väestö Suomessa keskimäärin. Laadullisen tutkimusaineiston mukaan suurin osa maitotiloilla työskentelevistä naisista kertoi kokevansa luonnonläheisen työn tuotantoeläinten parissa antoisana. Meneillään oleva rakennemuutos ja maatalouden harjoittamiseen liittyvät lisääntyneet riskit kuitenkin kuormittavat viljelijöiden arkea. Kirjallisuuskatsauksen mukaan stressiä aiheuttavat useimmin tilan taloudellinen tilanne, erilaiset maatalouden harjoittamiseen liittyvät säännöt, hallinto sekä luonnonolosuhteet.

Työhyvinvointiin liittyvistä ongelmista kertovat kyselyn tulokset: noin joka neljäs (26\%) päätoiminen viljelijä koki voimattomuutta tai väsymystä, noin joka viides (19\%) koki unettomuutta tai vaikeuksia nukahtaa ja $16 \%$ vastaajista koki ylirasittuneisuutta tai tunnetta siitä, että kaikki käy yli voimien. Ongelmat sosiaalisessa kanssakäymisessä ja terveydentilassa olivat yhteydessä oireiden kokemiseen. Lisäksi yli kaksi viikkoa kestänyt torjunta-aineiden ruiskutustyö edellisen kasvukauden aikana oli yhteydessä oireisiin. Myös kansainvälisten tutkimusten mukaan torjunta-aineille altistuminen on yhteydessä viljelijöiden henkisen hyvinvoinnin ongelmiin, kuten masennukseen.

Melan tilastojen mukaan kotieläinten hoitotyöt olivat vuonna 2012 työvaihe, jossa yleisimmin (43\% kaikista työtapaturmista) sattui vakuutetuille maatalousyrittäjille työtapaturmia. Laadullisessa tutkimuksessa selvitettiin, miksi tapaturmien määrässä oli huomattavia eroja eri maitotilojen kesken. Tulosten mukaan luottamuksellinen, hyvä vuorovaikutussuhde eläinten kanssa, hoidon rutiininomaisuus, tietämys eläinten luontaisesta käyttäytymisestä ja eläinten stressin kokonaisvaltainen välttäminen auttavat vähitellen luomaan hoitajalle turvalliset työolosuhteet.

Maatiloilla työskentelevillä naisilla on tärkeä rooli eläinten hyvinvoinnin vaalijoina ja kestävän maatalouden rakentajina. Suurin osa maidontuotantotiloilla työskentelevistä naisista halusi olla ammattinimikkeeltään maatalousyrittäjä. Oma jaksaminen oli haastatteluissa toistuva teema. Myös töihin vaikuttavat vanhat ajattelumallit tulivat keskusteluissa esiin. Töiden järjestäminen oman tai puolison sairauden aikana huolestutti, eikä lomalle lähteminenkään ollut helppoa.

Kotieläinten hoitajien hyvinvoinnilla on kirjallisuuslähteiden mukaan yhteys työturvallisuuteen, elintarvikkeiden laatuun ja eläinten hyvinvointiin. Maaseudulle ominaiset pitkät välimatkat, omavaraisuutta korostava ajattelu sekä häpeä vaikeuttavat hyvinvoinnin ongelmiin puuttumista. Työhyvinvointi maatiloilla on osa ruuantuotannon vastuullisuutta ja kestävyyttä.

Asiasanat: maatalous, työhyvinvointi, stressi, oireet, turvallisuus, nainen, työolosuhteet 


\section{Johdanto}

Viime vuosikymmeninä jatkunut maatalouden rakennemuutos on kasvattanut maatilojen kokoa ja samalla tilojen määrä on vähentynyt. Vuoden 1995 EU-jäsenyyden jälkeen vakuutettujen viljelijöiden ja perheenjäsenten määrä on vähentynyt miltei puolella, kun liki 66000 työpaikkaa on hävinnyt alalta. Samalla työala on muuttunut yritysmäisemmäksi. Kansainvälinen maataloustuotteiden kauppa on aikaansaanut maataloustuotteiden hintavaihteluita, ja riskit alalla ovat lisääntyneet. Maatilojen koon kasvattaminen vaatii huomattavia investointeja ja työala on tullut aiempaa riippuvaisemmaksi poliittisesta päätöksenteosta. Viime vuosina myös vaateet kilpailukykyisestä ja kustannustehokkaasta maataloustuotannosta ovat lisääntyneet.

Niemi (2010) arvioi, että pohjoisen ilmaston ja melko pienen tilakoon takia Suomen on haasteellista sopeutua avoimille ja kilpailuille maataloustuotteiden markkinoille. Toisaalta kyselytutkimuksen mukaan ( $\mathrm{N}=3$ 900) runsas $80 \%$ suomalaisista oli samaa mieltä väitteen "Kotimaista ruuantuotantoa tarvitaan myös tulevaisuudessa" osalta (Jutila, 2013). Knuuttila ja Vatanen (2013) arvioivat, että elintarvikemarkkinoiden kotimaisuusaste oli $75 \%$ vuonna 2008, mutta tuotteiden valmistaminen ei ole nykyään mahdollista ilman tuontipanoksia.

Useissa tutkimuksissa kuvaillaan kehityskulkua, jossa viljelijäväestön asema yhteiskunnassa on heikentynyt. Samaan aikaan heidän pitää selviytyä uusien sekä perinteisten arvojen ja elämäntavan ristiaallokossa (Elger ym., 1995; Melberg, 2003; Lobley ym., 2004). Viljelijöiden on arvioitu olevan stressin osalta riskiryhmä (Monk, 2000; Lobley ym., 2004). Toisaalta norjalaisen tutkimuksen mukaan viljelijät selviytyvät kuormitustilanteista, koska heillä on kyky selviytyä ja etsiä ratkaisuja hankaliin elämäntilanteisiin (Melberg, 2003). Aiemmat tutkimustulokset viljelijöiden kuormittumisesta eivät ole yhteneviä.

Vuonna 2007 joka kolmas maatiloilla työskentelevä henkilö oli nainen, ja yhteensä naisia työskenteli maatiloilla liki 49 000. Virallisesti luokitellen naisia työskentelee maatiloilla viljelijän puolisoina (57\%), viljelijöinä tai yhtymien osakkaina (19\%), muina perheenjäseninä (18\%) ja palkattuina työntekijöinä (6 \%) (Tike, 2011). Viime vuosina maatiloilla työskentelevien naisten määrä ja osuus kaikista maatiloilla työskentelevistä on vähentynyt.

Maatalouselinkeinon huomattavat muutokset herättävät kysymyksen: miten maatalousyrittäjät ovat selviytyneet muutoksista? Ovatko alalla jatkavat henkilöitä, joilla on kapasiteettia luovia läpi alan haasteiden, vai onko viljelijöiden työhyvinvointi heikentynyt?

Artikkeliväitöskirja (Kallioniemi, 2013) koostuu viidestä tieteellisestä, asiantuntijatarkastetusta artikkelista (viitteet I-V). Väitöskirjan kokoava teema on työhyvinvointi suomalaisilla maatiloilla. Kvantitatiivisen tutkimusosuuden tavoitteena oli selvittää stressin (I) ja siihen liittyvien oireiden (II) esiintyvyyttä päätoimisilla suomalaisilla viljelijöillä ( $N=1$ 182) haastattelututkimuksessa vuonna 2004. Lisäksi selvitettiin, mitkä taustamuuttujat olivat yhteydessä stressin kokemiseen (I) ja siihen liittyviin oireisiin (II). Laadullisen tutkimusosuuden tavoitteena oli selvittää, miksi työtapaturmien määrä vaihteli aineiston eri lypsykarjatiloilla (III). Lisäksi tavoitteena oli kuvailla naisten $(\mathrm{N}=10)$ työtä ja työolosuhteita lypsykarjatiloilla (IV).

\section{Aineisto ja menetelmät}

Vuosina 2004-2006 Työterveyslaitos toteutti viidennen, laajan seurantatutkimuksen, jonka tavoitteena oli tutkia maatalousyrittäjien työoloja ja terveyttä (Rissanen toim., 2006). Tässä tutkimuksessa haasteltiin vuonna 2004 yhteensä 1182 päätoimista maatalousyrittäjää, joista $77 \%$ oli miehiä ja $23 \%$ naisia. Vastausprosentti puhelimitse toteutettuun haastatteluun oli $86 \%$. Suomalaisten aktiivisten maatilojen aineistosta (vuonna 2004 yhteensä 71054 maatilaa) poimittiin satunnaisesti 6000 tilan otos, joista hyväksyttiin tutkimukseen mukaan 5127 tilaa. Kaikkiaan 2118 henkilöä haastateltiin, joista 1182 oli päätoimisia viljelijöitä. Maatilojen maantieteellinen sijainti vastasi kaikkien suomalaisten maatilojen alueellista sijoittumista, mutta toisaalta aineiston maatilat olivat hieman keskimääräistä isompia, haastatellut olivat vähän nuorempia ja lypsykarjayrittäjien osuus oli suurempi kuin kaikkien suomalaisten maatilojen tuotantosuuntajakaumassa.

Haastatteluun sisältyi kysymys stressin kokemisesta (I). Tämä sama stressikysymysmittari (Elo ym., 2003) on ollut mukana useissa suomalaisissa tutkimuksissa. Viljelijöiden vastauksia oli mahdollista verrata vuonna 2003 toteutetun "Työ ja terveys Suomessa 2003"-tutkimuksen (N=2 335) tuloksiin eli suomalaisten työikäisten vastauksiin (Piirainen ym., 2003). Lisäksi haastattelussa tiedus- 
teltiin stressiin liittyvien 12 oireen kokemisesta (II). Oireiden kokemista oli mahdollista verrata viljelijöiden edellisen seurantatutkimuksen tuloksiin vuodelta 1992 (II), sillä myös vuoden 1992 puhelinhaastattelututkimukseen sisältyi sama oirekysymys. Sekä stressin että siihen liittyvien oireiden yhteyttä taustamuuttujiin selvitettiin kahden logistisen regressioanalyysin avulla (I, II).

Laadullisen tutkimusaineiston kokoamista edelsi tieteellisen artikkelin kirjoittaminen suomeksi aiheesta "Naisten työturvallisuus maatiloilla" (Kallioniemi, 2008). Tilakäyntien pohjalta haastattelut litteroitiin sanatarkasti. Tämän jälkeen kirjoitettiin kuvailuteksti naisen työstä maatilalla. Haastatelluilla oli mahdollisuus halutessaan kommentoida ja korjata tutkimusaineiston kuvailutekstejä. Tekstit toimivat aineistomateriaaleina tieteellisille artikkeleille työturvallisuudesta karjanhoitotyössä (III) ja naisten työolosuhteista (IV).

Kesällä 2007 toteutettiin kymmenelle lypsykarjatilalle tilakäynti, jonka aikana ensin osallistuttiin lypsykarjan aamutöihin navetassa naisen työtä havainnoiden (III, IV). Tämän jälkeen toteutettiin puolistrukturoitu ja osin keskusteleva haastattelu, johon sisältyi kysymyksiä maatilasta, työnjaosta, työturvallisuudesta ja työhyvinvoinnista. Tutkimushankkeen ohjausryhmän asettamien kriteereiden pohjalta valittiin tutkimukseen mukaan 10 tilaa, joiden tavoittamisessa avustivat meijerin maidontuotantoneuvoja ja MTK:n alueellisen toimiston työntekijä. Maatilat sijaitsivat Varsinais-Suomen, Satakunnan ja Pirkanmaan maakunnissa. Tilakäynnit kestivät keskimäärin 5 tuntia ja 30 minuuttia (vaihtelu 3 h 40 min -8 h 15 min). Työturvallisuuteen liittyvässä artikkelissa (III) analysointimenetelmänä oli ankkuroitu teoria (grounded theory), johon liitettiin toimintatutkimuksen työtapaa. Keskeinen kysymys oli selvittää, mistä syystä työtapaturmien määrä vaihteli eri lypsykarjatilojen välillä. Naisten työolosuhteita analysoitiin tapaustutkimuksen avulla (IV), jota sovellettiin kokonaisvaltaisen lähestymistavan avulla. Analyysissä otettiin huomioon sosiaaliset suhteet, ympäristö, erilaiset liittymäpinnat ja työolosuhteiden vaihtelu. Havaintoja vertailtiin aiemmassa tutkimuskirjallisuudessa esitettyihin tuloksiin.

\section{Tulokset ja tulosten tarkastelu}

Myönteisenä haastatteluaineiston (I) tuloksena ilmeni, että päätoimiset viljelijät kokivat vähemmän stressiä (34 \%) kuin työikäinen väestö Suomessa keskimäärin (44 \%). Laadullisen tutkimusaineiston mukaan suurin osa maitotiloilla työskentelevistä naisista kertoi kokevansa luonnonläheisen työn tuotantoeläinten parissa antoisana (IV). Yrittäjän toimiminen mahdollisti maatilaan liittyvien työtehtävien rytmittämisen esimerkiksi lasten- tai vanhustenhoidon tarpeiden mukaan.

Työhyvinvointiin liittyvistä ongelmista kertovat puhelinkyselyn tulokset: noin joka neljäs (26 \%) päätoiminen viljelijä koki voimattomuutta tai väsymystä, noin joka viides (19\%) koki unettomuutta tai vaikeuksia nukahtaa (II). Nämä molemmat oireet olivat tilastollisesti merkitsevästi lisääntyneet edelliseen seurantatutkimukseen vuodelta 1992 verrattuna. Vuoden 1992 tutkimuksessa oire "unettomuus ja vaikeuksia nukahtaa" oli vasta seitsemännellä sijalla oireiden yleisyysjärjestyksessä, mutta vuoden 2004 haastattelututkimuksessa oire oli kohonnut toiselle sijalle. Vuoden 2004 haastattelussa $16 \%$ vastaajista oli kokenut oiretta "ylirasittuneisuutta tai tunnetta siitä, että kaikki käy yli voimien" kuluneen viimeisen kuukauden aikana.

Useissa muissa tutkimustuloksissa (Peltoniemi, 2005; Saarni ym., 2008; Martelin ym., 2010) on havaittu maatalousyrittäjien alhaisempi työkyky palkansaajiin ja muihin yrittäjiin verrattuna. Peltoniemen (2005) tutkimuksessa havaittiin lisäksi, että erityisen alhainen työkyky on maatiloilla työskentelevillä naisilla. Pensola ym. (2010) selvitti työkyvyttömyyseläkkeiden saajia Suomessa: suomalaisten naisten osalta työkyvyttömyyseläkkeitä myönnetään etenkin siivoojille, hoitoalalla työskenteleville, myyjille ja maatilojen naisille.Tilastokeskuksen ajankäyttötutkimuksen mukaan maatalousyrittäjämiesten on havaittu tekevän pisintä työpäivää muihin yrittäjiin ja palkansaajiin verrattuna (Pääkkönen ja Hanifi, 2011). Jos työaikaan lasketaan mukaan myös kotityöt, tekevät maatilojen naiset vielä pidempää päivää kuin maatilojen miehet seurantatutkimusten vuosilta 1987-1988 ja 1999-2000 mukaan (Pääkkönen ja Hanifi, 2011). Postikysely lypsykarjatiloilla vuonna 2010 (N=265) luokitteli kaikki vastaajat lievästi uupuneeksi, kun mittarina oli Maslach Burnout Inventory MBI-GS (Maslach ja Leiter, 1997). Miltei joka kymmenes vastaaja (9\%) oli vakavasti työuupunut (Kymäläinen toim., 2011).

Ongelmat sosiaalisessa kanssakäymisessä ja terveydentilassa olivat yhteydessä oireiden kokemiseen molemmissa analyyseissä (I, II). Stressin kokeminen oli yhteydessä etenkin siihen, että tuki 
puolisolta oli vähäistä, sekä siihen, että perheessä oli tietty henkilö, jonka kanssa oli vaikea keskustella. Eronneet tai asumuserossa olevat kokivat enemmän stressiä kuin viljelijäaineistossa keskimäärin. Yllättävä tulos oli stressin kokemisen liittyminen vastaajan opisto- tai yliopistotasoiseen koulutukseen. Myös lääkärin toteama sairaus tai vamma tai alhainen arvio omasta työkyvystä olivat yhteydessä stressin kokemiseen. Sen sijaan taustamuuttujat vastaajan ikä, sukupuoli ja maatilan koko eivät olleet yhteydessä stressin kokemiseen.

Yli kaksi viikkoa kestänyt torjunta-aineiden ruiskutustyö edellisen kasvukauden aikana oli yhteydessä stressin oireisiin (II). Kansainvälisten tutkimusten mukaan torjunta-aineille altistuminen on yhteydessä viljelijöiden henkisen hyvinvoinnin ongelmiin, kuten masennukseen (Beseler ym., 2008). Torjunta-aineiden, erityisesti organofosfaattien, on arvioitu olevan neurotoksisia eli hermostolle myrkyllisiä. Pitkäaikainen altistuminen hidastaa aivotoimintoja, aistitarkkuus heikkenee ja unettomuus sekä mielialan vaihtelut lisääntyvät (Merchant ja Reynolds, 2008). Meillä Suomessa torjunta-aineiden käyttömäärät ovat lisääntyneet viime vuosina suorakylvön ja viljakasvien viljelyn yleistymisen myötä (Miettinen, 2013). Kirjaan "Handbook of Stress in the Occupations" kirjoitetun kirjallisuuskatsauksen mukaan stressiä aiheuttavat useimmin tilan taloudellinen tilanne, erilaiset maatalouden harjoittamiseen liittyvät säännöt, hallinto sekä luonnonolosuhteet (V).

Turvallinen työympäristö on osa työhyvinvointia. Melan tilastojen mukaan kotieläinten hoitotyöt olivat vuonna 2012 työvaihe, jossa yleisimmin (43\% kaikista työtapaturmista) sattui vakuutetuille maatalousyrittäjille työtapaturmia. Naisten tapaturmista suurin osa (76\%) sattui eläinten hoitotyön aikana (Tilastokeskus, 2011).

Laadullisessa tutkimuksessa (III) selvitettiin, miksi tapaturmien määrässä oli huomattavia eroja eri lypsykarjatilojen kesken. Seuraavassa mainittavat tutkittavien nimet eivät ole oikeita vaan peitenimiä. Riikka ja Tuula kertoivat haastattelussa viimeksi tapahtuneesta tapaturmasta ja sairauslomasta, mutta niistä oli vierähtänyt viidestätoista kahteenkymmeneen vuotta aikaa. Turvallinen työ oli ollut heille osa arkea pitkään. Anneli ja Mari taas kuvailivat haastattelun aikana lukuisia eläimiin liittyviä tapaturmia. Esimerkiksi Anneli oli jäänyt säikähtäneen naudan ja seinän väliin puristuksiin. Maria lehmä oli potkaissut otsaan lypsyn aikana.

Laadullisessa aineistossa havaittiin erilaisia toimintamalleja, joilla voidaan parantaa työturvallisuutta navetassa (III). Työturvallisuutta oli parannettu muuttamalla navetan olosuhteita siten, että naudoilla olisi rauhallinen, viihtyisä ja selkeä elinympäristö. Eläinten luontaista käyttäytymistä sekä ihmisen ja eläimen positiivista vuorovaikutusta haluttiin ymmärtää ja edistää. Hoitajat kertoivat hoidettavien nautojen luonteenpiirteistä. Hoitotöissä noudatettiin lempeitä rutiineja, kiireettömyyttä ja olosuhteiden samanlaisuutta. Aina piti olla kuitenkin valmistautunut puolustamaan itseään, vaikka eläimen stressin ja pelon välttäminen oli hoitotyön arkea. Eläimen sairaus, loukkaantuminen, hormonimuutokset tai tarve puolustaa jälkeläistä voivat muuttaa naudan käyttäytymisen hoitajalle vaaralliseksi ja arvaamattomaksi. Nautojen joukossa liikkuessa olisi hyvä olla aina mukana jotain, jonka avulla on mahdollista tarpeen vaatiessa puolustaa itseään. Tarkoitukseen soveltuvat esimerkiksi keppi tai lantakola. Naudan hyökkäysaikeet voi yrittää torjua myös voimakkaasti huutamalla ja käsiä ylös nostamalla.

Laadullisen tutkimuksen tulosten mukaan luottamuksellinen, hyvä vuorovaikutussuhde eläinten kanssa, hoidon rutiininomaisuus, tietämys eläinten luontaisesta käyttäytymisestä ja eläinten stressin kokonaisvaltainen välttäminen auttavat vähitellen luomaan hoitajalle turvalliset työolosuhteet (III). Käytännön ohjeina mainittakoon esimerkiksi, että vasikka on hyvä totuttaa ihmisiin jo ensimmäisistä elinpäivistä lähtien esimerkiksi rapsuttamalla ja puhumalla sille ruokinnan yhteydessä. Naudan siirtojen aikana tulisi olla kärsivällinen ja odottaa rauhassa kömpelömmän eläimen etenemistä. Naudalla on laaja näkökyky, mutta aivan taakseen se ei kykene näkemään. Siten hoitajan on hyvä ilmoittaa jollakin tavoin lähestymisestään. Laumaeläimiä on helpompi siirtää ryhmänä. Jos yksi nauta pitää erottaa ryhmästä, olisi hyvä erottaa samalle sille myös kaveri. Hoitaja voi soveltaa omia, persoonallisia tapojaan positiivisen vuorovaikutuksen luomisessa: esimerkiksi Noora tervehti lypsylle saapuvia nautoja nimeltä ja jutteli niille. Kristiina taas seurasi poikivan lehmän liikkeitä ja eleitä, sillä hän osasi tulkita, milloin nauta pyytää häneltä apua.

Suurin osa (6) lypsykarjatiloilla työskentelevistä naisista valitsi ammattinimikkeekseen maatalousyrittäjä (IV). Emännän valitsi ammattinimikkeekseen kolme haastateltua ja yksi halusi olla maanviljelijä. Kysymys ammattinimikkeestä aikaansai keskustelua. Naisten ammatillinen asema tuntui olevan osin vaihteleva ja osin väärin ymmärretty. Naiset tekivät tiloilla monenlaisia työtehtäviä aloittaen navetassa keskimäärin aamukuudelta, ja työ navetalla loppui keskimäärin puoli seitsemältä illalla. 
Molemmilla tiloilla, joilla oli käytössä automaattinen lypsyjärjestelmä, nainen oli järjestelmän pääkäyttäjä. Naiset suunnittelivat tilan toimintoja ja pohtivat tulevaisuuden osalta eri vaihtoehtoja. Neljä naista osallistui myös peltotöihin. Nooralla ja Sadulla oli kiireisinä toukotyö- ja sadonkorjuuaikoina tietyn koneen ajaminen vastuullaan.

Toisaalta naiset tekivät navetassa paljon fyysisiä työvaiheita, jotka vaativat taakkojen kantamista, kannattelua ja kumarassa työskentelyä. Miltei kaikki (8) haastatellut arvioivat, että työn pölyisyys on työympäristön riskitekijä. Seitsemässä haastattelussa työympäristön riskitekijöiksi arvioitiin myös hankalat työasennot, nostot, taakkojen kannattelu, melu ja maatalouskemikaalit. Puolet (5) naisista arvioi, että työtaakka on liian suuri, ja samoin puolet oli tuntenut itsensä ylirasittuneeksi tai kokenut tunnetta siitä, että kaikki oli käynyt viimeksi kuluneen kuukauden aikana yli voimien (IV).

Haastateltuja naisia stressasi töiden järjestäminen ja tilan toimintojen turvaaminen tilanteissa, joissa jompikumpi puolisoista ei kykene tekemään työtehtäviään (IV). Oma tai puolison sairastuminen koettiin todellisena riskitekijänä tilan toimintojen jatkuvuuden osalta. "Pienten" sairastumisten kuten flunssan aikana otettiin särkylääkettä ja yritettiin selviytyä työtehtävistä, sillä sijaisen saaminen nopeasti ei ollut aina mahdollista. Lomalle lähteminen koettiin etukäteisjärjestelyineen työläänä, ja osalla tiloista puolisoiden yhtäaikaisen loman koettiin vaativan liian hankalia järjestelyjä. Myös naisten arkeen vaikuttavat vanhat ajattelumallit, kuten naisen rooli omavaraisena (vrt. verkostoituneena) henkilönä, "oikean" työnteon luokittelu pelkästään fyysisenä työnä (vrt. myös toimistotyönä), sosiaalisen kanssakäymisen kirjoittamattomat säännöt, työnjako sukupuolen mukaan ja kotitöiden asema tulivat keskusteluissa esiin. Työtä ja kotia, työkaveria ja puolisoa, työ- ja vapaa-aikaa sekä julkista ja yksityistä on maatilalla vaikea erottaa toisistaan, sillä ne kietoutuvat vyyhdiksi. Oma jaksaminen oli haastatteluissa toistuva teema.

\section{Johtopäätökset}

Tulokset laajasta haastatteluaineistosta kertovat edustavan otoksen avulla viljelijöiden työhyvinvointiin liittyvien stressin ja sen oireiden esiintymisestä. Logistinen regressioanalyysi toi esiin, mitkä taustamuuttujat olivat yhteydessä stressiin ja sen oireisiin. Laadullinen tutkimusaineisto ei kykene olemaan edustava, mutta toisaalta se tuo elämänläheisesti esiin maatilojen arkea ja työhyvinvointiin vaikuttavia piirteitä lypsykarjatiloilla naisten kertomana.

Tässä tutkimuksessa ilmeni myös myönteisiä piirteitä viljelijöiden työhyvinvoinnin osalta kuten vähäisempi stressin kokeminen työikäisiin suomalaisiin verrattuna. Toisaalta kvantitatiivisessa tutkimusosuudessa tulivat esiin viljelijoiden yleisinä oireina voimattomuus tai väsymys (joka neljännellä), unettomuus tai vaikeuksia nukahtaa (joka viidennellä). Kolmanneksi yleisin (16\%) oire oli tunne ylirasittuneisuudesta ja siitä, että kaikki käy yli voimien. Nämä oireet kertovat uupumisen riskistä.

Kotieläinten hoitajien hyvinvoinnilla on kirjallisuuslähteiden mukaan yhteys työturvallisuuteen, elintarvikkeiden laatuun ja eläinten hyvinvointiin. Maaseudulle ominaiset pitkät välimatkat, omavaraisuutta korostava ajattelu sekä häpeä vaikeuttavat hyvinvoinnin ongelmiin puuttumista. Työhyvinvointi maatiloilla on osa ruuantuotannon vastuullisuutta ja kestävyyttä. Maatiloilla työskentelevillä naisilla on tärkeä rooli eläinten hyvinvoinnin vaalijoina ja kestävän maatalouden rakentajina.

Millaisin keinoin työhyvinvointia maatiloilla voitaisiin kohentaa? Parry ym. (2005) arvioivat, että viljelijät välttelevät omista ongelmistaan puhumista eivätkä helposti pyydä apua psyykkisiin ongelmiin. Siten ongelmat saattavat ilmetä vasta hyvin myöhäisessä vaiheessa, kun tilanne on "karkaamassa käsistä". Keating (1987) kuvailee, kuinka viljelijät ovat tottuneet ratkomaan omin avuin erilaisia tilanteita, siten hän rohkaisee tarjoamaan viljelijöille työkaluja hallita kuormitustilanteita seuraavien neljän toimintamallin ja-askeleen avulla.

a) Ajatellaan myönteisesti. Arvioi omia tunteitasi ja reaktioitasi. Yritä vähentää sitä, että näet ongelmatilanteet negatiivisten asioiden vyyhtinä. Mieti, miten vaatimuksia olisi mahdollista hallita.

b) Etsitään tietoja, neuvoja ja taustainformaatiota. Luo itsellesi tietolähde- ja asiantuntijaverkosto. Nykyisin internet tarjoaa tietolähteitä, joskin lähteiden luotettavuutta kannattaa kriittisesti arvioida. c) Toimi! Älä jää ainakaan kovin pitkäksi aikaa pelkästään murehtimaan tilannetta. Yritä ottaa edes pieniä askeleita: paranna ajanhallintaa, järjestele toisin vaikeita tehtäviä ja kehitä ongelmanratkaisua. Vältä luovuttamista, suuttumista tai asioiden "hoitamista" alkoholia tai päihteitä käyttämällä.

d) Keskustele omasta tilanteestasi muiden kanssa. Etsi sopiva, luotettava taho, sillä puhuen järjestelet ja pohdit tilannettasi myös itsellesi. Mahdollisesti opit läheiseltäsi jotain uutta tai kehittelette yhdessä 
jonkin käyttökelpoisen keinon edetä. Myös uskonto tai perheen tuki voivat olla tärkeitä tukipilareita. Keating (1987) arvioi, että sosiaalisen tukiverkoston vaaliminen on ehkä yksi kaikkein parhaimmista keinoista varautua stressaaviin elämäntilanteisiin.

\section{Kirjallisuus}

Beseler, C. L., Stallones, L., Hoppin, J. A., Alavanja, M. C. R., Blair, A. \& Keefe, T. 2008. Depression and Pesticide Exposures among Private pesticide applicators Enrolled in the Agricultural Health Study. Environmental Health Perspectives 116 (12): 1713-1719.

Elger, U., Wonneberger, E., Lasch, V., Fuhr, D. \& Heinzel, W. 1995. Belastungen und gesundheitliche Risiken von Bäuerinnen. Sozial- und Praventivmedizin 40 (3): 146-156.

Elo, A.-L., Leppänen, A. \& Jahkola, A. 2003. Validity of a single-item measure of stress symptoms. Scandinavian Journal of Work, Environment and Health 29 (6): 444-451.

Jutila, K. 2013. Lähiruokaa, kiitos! Mutta ... Tutkimus suomalaisten ruoka- ja maatalousasenteista. Taloustutkimus Oy, Ajatuspaja e2. URL

http://www.mtk.fi/ajankohtaista/tiedotteet/tiedotteet_2013/tammikuu/fi_FI/tutkimus_suomalaisten ruoka ja ma atalousaseta_tukea_kotimaiselle_ruualle_ja_ympariston_huomioimiselle/_files/89105455227275818/default/LA HIRUOKAA, \%20KIITOS.pdf

Kallioniemi M. 2008. Naisten työturvallisuus maatiloilla. pp. 115-138. teoksessa: Ikonen H.-M. (toim.) 2008. Syrjäsilmällä - sukupuolen jäsennyksiä maaseudulla. Maaseutupolitiikan yhteistyöryhmän julkaisu 4/2008, Vammala. Saatavilla: http://www.maaseutupolitiikka.fi/files/547/YTR_4_net.pdf

Kallioniemi, M. 2013. Well-being at Work on Farms in Finland. Stress, Safety in Animal Handling and Working Conditions of Women on Dairy Farms. Väitöskirja. MTT Science, MTT Tiede 21: $91 \mathrm{s.}$

Keating, N. C. 1987. Reducing Stress of Farm Men and Women. Family Relations 36 (4): 358-363.

Knuuttila, M. \& Vatanen, E. 2013. Kotimainen elintarviketuotanto on tuonnin varassa. Teoksessa Jyrki Niemi \& Jaana Ahlstedt (toim.) Suomen maatalous ja maaseutuelinkeinot 2013. Julkaisuja 114. Helsinki: Maa- ja elintarviketalouden tutkimuskeskus, Taloustutkimus, 46-47. URL

https://portal.mtt.fi/portal/page/portal/mtt/mtt/julkaisut/suomenmaatalousjamaaseutuelinkeinot

Kymäläinen, H.-R. (toim.) 2011. Maitotilan hyvä vointi. Tutkimushankkeen loppuraportti. Maataloustieteen laitos, julkaisuja 9. Helsingin yliopisto.

Lobley, M., Johnson, G., Reed M., Winter, M. \& Little, J. 2004. Rural Stress Review, Final Report. Research Report No:7. Centre for Rural Research, University of Exeter.

Maslach, C. \& Leiter, M. P. 1997. The truth about burnout. San Francisco, USA: Jossey-Bass.

Martelin, T., Sainio, P., Polvinen, A., Pensola, T., Koskinen, S. \& Goud, R. 2010. Työkyky eri väestöryhmissä. pp. 39-45. Teoksessa: Aromaa, A. \& Koskinen, S. (toim.) Suomalaisten työ, työkyky ja terveys 2000-luvun alkaessa. Raportti 11/2010. Terveyden ja hyvinvoinnin laitos. Helsinki: Yliopistopaino.

Melberg, K. 2003. Farming, Stress and Psychological Well-being: The Case of Norwegian Farm Spouses. Sociologia Ruralis, 43 (1): 56-76.

Merchant, J. \& Reynolds, S. 2008. Work in agriculture. Teoksessa: McDonald, C. (toim.) Epidemiology of Work Related Diseases. Hoboken, USA: BMJ Books, s. 309-329.

Miettinen, A. 2013. Maatalous ja ympäristö. s. 67-75. Teoksessa: Niemi, J. \& Ahlstedt J. (toim). Suomen maatalous ja maaseutuelinkeinot 2013. MTT Taloustutkimus. Julkaisuja 114. Vammalan kirjapaino Oy.

Monk, A. 2000. The Influence of Isolation on Stress and Suicide in Rural Areas: An international comparison. Rural Society, 10 (3): 393-403.

Niemi, J. 2010. Summary - First 15 years in the EU for Finnish agriculture and food economy. s. 5-9. Teoksessa: Niemi, J. \& Ahlstedt, J. (Eds.), Finnish Agriculture and Rural Industries 2010. Publications 110a. Vammala, Finland: MTT Agrifood Research Finland.

Parry, J., Barnes, H., Lindsey, R. \& Taylor, R. 2005. Farmers, Farm Workers and Work-Related Stress. Research Report 362. Health \& Safety Executive. Suffolk, UK: HSE Books.

Peltoniemi, A. 2005. Työllisten työkyky vuonna 2004. Työpoliittinen tutkimus. Nro 273. Helsinki: Työministeriö.

Pensola, T., Gould, R. \& Polvinen, A. 2010. Ammatit and työkyvyttömyyseläkkeet. Sosiaali- ja terveysministeriön selvityksiä 2010:16. Helsinki: Sosiaali- ja terveysministeriö.

Piirainen, H., Hirvonen, M., Elo, A.-L., Huuhtanen, P., Kandolin, I., Kauppinen, K., Ketola, R., Lindström, K., Salminen, S., Reijula, K., Riala, R., Toivanen, M., Viluksela, M. \& Virtanen, S. 2003. Työ ja terveys haastattelututkimus. Taulukkoraportti. Helsinki: Työterveyslaitos.

Rissanen P. (toim.) 2006. Työterveys ja maatalous Suomessa 2004. Kuopio: Työterveyslaitos.

Pääkkönen, H. \& Hanifi, R. 2011. Ajankäytön muutokset 2000-luvulla. Helsinki: Tilastokeskus. 
Saarni, S. I., Saarni, E. S., Saarni, H. 2008. Quality of life, work ability, and self employment: a population survey of entrepreneurs, farmers, and salary earners. Occupational and Environmental Medicine 65 (2): 98-103. Tike, 2011. Yearbook of Farm Statistics 2011. Helsinki, Finland: Information Centre of the Ministry of Agriculture and Forestry.

Tilastokeskus, 2011. Työtapaturmat 2009. Työmarkkinat. URL http://www.stat.fi/ti1/ttap/2009/ttap_2009_2011$\underline{11-30 \text { fi.pdf }}$ 